\title{
EVALUASI PENYEDIAAN FASILITAS PENGELOLAAN SAMPAH (INSINERATOR) DI DESA KRANGGAN
}

\author{
Alfiandri' ${ }^{1}$, Evita H. Legowo ${ }^{2}$, Kholis Abdurrahman Audah ${ }^{3}$ \\ ${ }^{1}$ Universitas Swiss German \\ ${ }^{2}$ Universitas Swiss German \\ ${ }^{3}$ Universitas Swiss German
}

alfiandri@sgu.ac.id, evita.legowo@sgu.ac.id,kholis.audah@sgu.ac.id

\begin{abstract}
Abstrak
Salah satu peta jalan aktifitas pengabdian masyarakat tahun 2016 - 2020 pada Universitas Swiss German adalah tentang pengelolaan limbah sampah non organik. Desa Keranggan merupakan desa binaan dan sekaligus percontohan untuk pengelolaan limbah sampah non organik yang berlokasi di wilayah kabupaten Tangerang, Provinsi Banten, Indonesia. Universitas Swiss German menyediakan fasilitas pengelolaan sampah non organik yang berguna untuk membakar sampah non organic. Fasilitas tersebut adalah insinerator sederhana. Aktifitas ini telah dilakukan di tahun 2018. Selanjutnya dilakukan evaluasi atas penggunaan alat insinerator di tahun 2019. Hasil dari evaluasi menunjukan bahwa alat insinerator sederhana tersebut jarang digunakan untuk pembakaran sampah sehingga berdampak terhadap lingkungan sekitar. Hal ini menjadi input bagi LPPM SGU untuk melaksanakan aktifitas pengabdian masyarakat di Desa Keranggan tersebut agar lingkungan di desa Keranggan tersebut menjadi bersih
\end{abstract}

Kata Kunci : Pengelolaan Sampah, Fasilitas pengelolaan sampah, sampah non organic, kebersihan lingkungan, Desa Binaan.

\section{PENDAHULUAN}

Dewasa ini upaya peningkatan kualitas lingkungan hidup telah dilaksanakan oleh sebagian besar Pemerintah Daerah dan Kota di Indonesia melalui pencanangan berbagai program yang relevan. Peningkatan kualitas lingkungan terdiri dari berbagai aspek, salah satu aspek yang sangat berpengaruh adalah aspek pengelolaan sampah di lingkungan permukiman. Menurut Wibowo dan Darwin (2006) persampahan telah menjadi agenda permasalahan utama yang dihadapi oleh hampir seluruh daerah di Indonesia. Faktor keberhasilan pelaksanaan pengelolaan sampah sepenuhnya akan tergantung pada kemauan Pemerintah Daerah atau Kota dan masyarakat. Kemauan ini dapat di mulai dari pemahaman dan kesadaran akan pentingnya sektor pengelolaan sampah sebagai salah satu pencerminan keberhasilan pengelolaan kota dan daerah.

Desa Kranggan adalah salah satu desa yang berlokasi di daerah Tangerang, Indonesia. Desa tersebut bertempat di Lingkar Selatan perbatasan Kabupaten Tangerang dan Tangsel. Desa yang masih didominasi warga pribumi ini, memiliki banyak pelaku industri baik kacang sangrai, dan lainnya. Dengan kearifan lokal ini Pemerintah Kota Tangerang Selatan menjadikan Kampung Kranggan sebagai "Kampung Ekowisata atau Kampung Pariwisata Industri" yang mana desa tersebut dijadikan sebagai pusat industri rumahan. Masyarakat memproduksi berbagai macam produk makanan seperti peyek, emping, kerupuk, dodol, 
kripik, kacang sanggrai, kue basah, lopis ataupun singkong. Dijadikannya Desa Kranggan sebagai "Kampung Ekowisata atau Kampung Pariwisata Industri", maka dibutuhkan pengelolaan sampah yang baik sehingga desa tersebut bersih dari segala kotoran, bau dan penyakit. Namun kenyataanya, Desa Keranggan mengalami permasalahan dalam pengelolaan sampah baik sampah rumahan dan juga sampah hasil produksi rumahan (home industry). Selama ini pengelolaan sampah di Desa Keranggan sebatas penanganan sampah dan belum maksimal. Penanganan sampah yang dilakukan yaitu dengan cara mengumpulkan dan membakar sampah pada tempatnya dan sisa atau sebagiannya diangkut dan di buang ke TPS (Tempat Pembuangan Sampah).

Hal tersebut menjadi pemicu bagi akademisi Universitas Swiss German untuk mengedukasi dan juga menfasilitasi pengadaan tempat sampah serta alat untuk pembakaran tempat sampah yaitu Insinerator kepada masyarakat Desa Keranggan dengan harapan dapat mengurangi limbah sampah serta menjadikan lingkungan desa keranggan menjadi bersih dan sehat sehingga mencerminkan sebagai "Kampung Ekowisata atau Kampung Pariwisata Industri" seperti yang di canangkan oleh pemerintah Kota Tangerang Selatan. Ini merupakan salah satu bentuk pegabdian masyarakat dari universitas swiss german.

Pengadaan tempat pembakaran sampah atau disebut Insenerator merupakan salah satu cara untuk mengurangi limbah sampah dengan cara membakar dan hasil pembakaran sampah tersebut (Abu) dapat digunakan kembali untuk memproduksi batu bata. Ini merupakan metode recycle (Mendaur ulang) yang mana nilai ekonomis yang terkandung di dalam sampah masih dapat dimanfaatkan (P3M, 2014) sehingga dapat meningkat ekonomi masyarakat Desa Kranggan. Universitas Swiss German menyediakan 3 (tiga) unit alat insinerator dan ditempatkan di lokasi yang berbeda, sekaligus juga menghibahkan 2 (dua) unit tempat sampah.

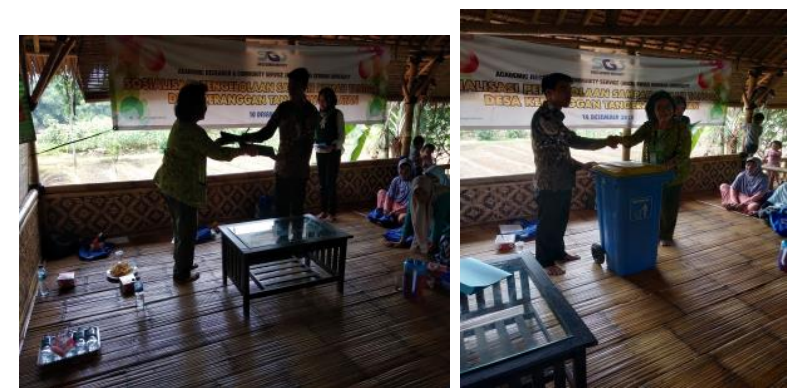

Gambar 1. Serah Terima alat incinerator dan tempat sampah ke masyarakat desa Keranggan.

Tahap selanjutnya untuk kegiatan ini adalah monitoring dan evaluasi atas penyediaan alat insinerator dan dampak terhadap lingkungan sekitar.

\section{METODE}

Monitoring dan evaluasi dilakukan pada bulan Februari 2019 hingga Juni 2019 bertempat di Desa Keranggan, Tangerang. Pengumpulan data dilakukan dengan cara pengumpulan data primer yang mana dilakukan pengamatan dan wawancara langsung di lapangan. Tahap dalam metode data primer ini meliputi:

1. Pengamatan langsung dilakukan di titik-titik penempatan alat insenerator yang telah ditunjuk bersama sekaligus melakukan pengamatan atas dampak penggunaan alat insenerator terhadap lingkungan disekitar.

2. Melakukan wawancara langsung dengan masyarakat setempat tentang penggunaan alatalat insinerator sederhana tersebut.

3. Serta melakukan koordinasi dengan penanggung jawab atas pengelolaan alat incinerator serta aktifitas-aktifitas nya.

\section{HASIL DAN PEMBAHASAN}

\section{Kondisi Umum Area Pembuangan Sampah Desa Keranggan.}

Area tempat pembuangan sampah telah ditunjuk di tiga tempat tertentu. Tempat pertama (1) berlokasi di belakang café yang mana tempat tersebut juga ditempatkan alat insinerator untuk pembakaran sampah hasil usaha dari café serta beberapa rumah di sekitaran café tersebut yang merupakan sampah organic. Tempat atau area tersebut juga digunakan oleh masyarakat sekitar untuk pembuangan serta 
pembakaran sampah rumah tangga dari hasil industry rumah tangga.

Tempat atau area ke kedua (2) bertempat di pinggiran sungai cisadane yang dimana banyak bermukim rumah penduduk yang juga merupakan pelaku home industry sehingga banyak menghasil kan sampah organic. Di tempatkan alat incinerator mini di tempat/area tersebut, gunanya untuk mencegah masyarkat membuang sampah organic di sungai cisadane.

Tempat atau area ke tiga (3) bertempat di area perbukitan pemukiman di desa Keranggan. Di area tersebut bermukim rumah penduduk yang juga merupakan pelaku home industri. Ditempatkan alat insinirator di area tersebut, sebagai fasilitas untuk pembakaran sampah, agar lingkungan di sekitar bersih dari pada sampah rumah tangga dan sampah home industri.

\section{Penggunaan alat Insinerator oleh Masyarakat dan dampak terhadap lingkungan sekitar}

Dari hasil observasi/pengamatan langsung di lapangan menunjukan masih kurang nya kesadaran masyarakat sekitar untuk buang sampah pada tempat nya. Hal ini ditunjukkan kurang nya memaksimalkan penggunaan alat incinerator tersebut untuk pembakaran sampah di sekitar nya dan juga kurangnya pemeliharaan alat insinerator, ini seperti yang tergambar pada gambar 1 berikut ini

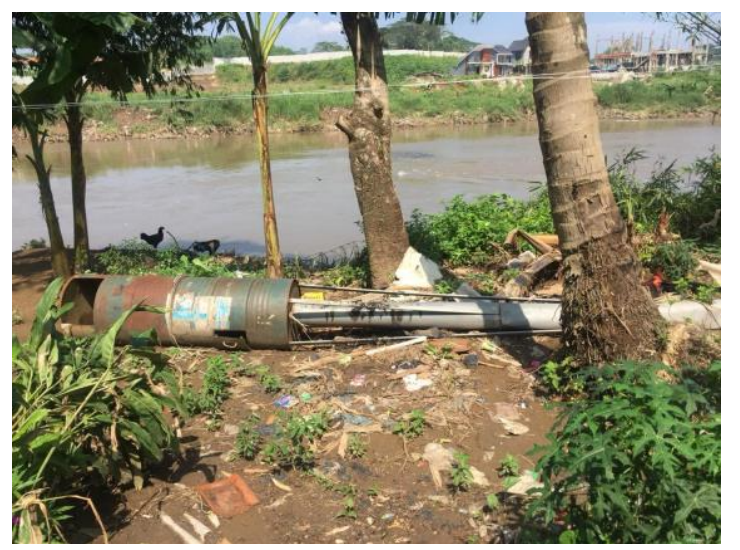

Gambar 1 - Alat Insinerator berlokasi di dekat sungai Cisadane

Gambar 1 menunjukan alat insinerator yang bertempat di area 2 yaitu berdekatan dengan sungai Cisadane.
Dari hasil observasi dan diskusi dengan masyarakat lingkungan sekitar, bahwa alat tersebut tidak pernah dimanfaatkan untuk pembakaran sampah oleh masyarakat setempat dan alat tersebut hanya dibiarkan saja hingga rubuh ketika banjir besar datang meluap dari sungai Cisadane hingga akhirnya menjadi barang rongsokan tua. Dikarenakan tidak dimanfaatkan alat tersebut maka berdampak terhadap lingkungan di wilayah tersebut. Lingkungan bertambah kotor ditambah sampah dari luapan banjir sungai Cisadane.

Hal ini juga terjadi pada alat insinerator yang bertempat di Area 3 yang mana sama hal nya dengan alat insinerator di Area 2, yang mana tidak dimanfaatkan dan rusak hingga menjadi alat rongsokan tua. Masyarakat di dua area tersebut cenderung membuang sampah ditempat yang bukan pada tempatnya. Sehingga menimbulkan bau kotor dan banyak nya nyamuk dan nanti nya berdampak pada kesehatan masyarakat di wilayah tersebut.

Namun demikian, 1 buah alat insinerator mini yang ditempatkan di area 1 digunakan. Yaitu bertempat di belakang Café. Namun tidak dapat bertahan lama dikarenakan ketidaktahanan material yang ada pada di alat tersebut atas panas pembakaran sampah serta hujan. Atas ketidaktahanan panas dan dingin tersebut drum serta corong asap menjadi rapuh dan rusak. Ini seperti yang terlihat pada gambar 2 dibawah ini

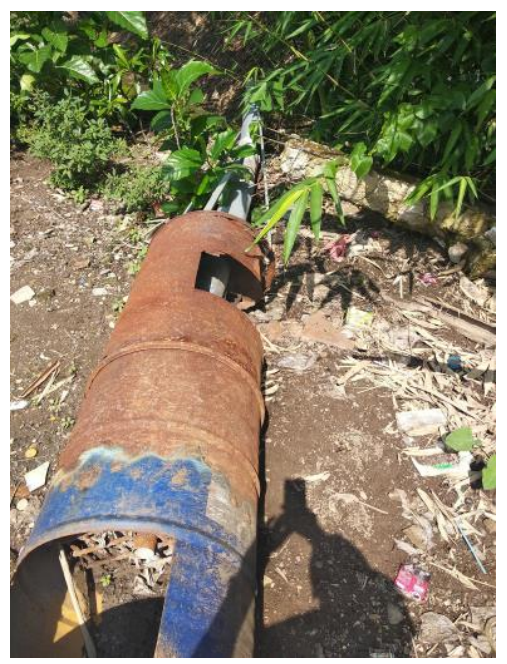

Hal ini juga diutarakan oleh pengelola sampah di wilayah area 1 bahwa alat tidak mampu bertahan lama dikarenakan pembakaran sampah dilakukan

$$
\text { Lingkungan Hidup dan Bencana }
$$


dalam 2 hari sekali dan menyebabkan drum menjadi rapuh ditambah lagi dengan hujan. Dengan suhu yang panas dan dingin tersebut membuat pinggiran drum menjadi berlobang, sama hal nya dengan pinggiran corong asap menjadi berlobang dan rapuh serta pengikat tumpuan corong asap menjadi rapuh juga dan patah. Dengan ini alat tidak dapat berfungsi kembali sehingga berdampak terhadap lingkungan disekitar area 1. Pengelola sampah di area 1 meminta agar di buat kembali dengan men design ulang alat insinerator tersebut sehingga alat mampu menahan panas dan dingin nya suhu udara sehingga alat dapat dipakai dalam waktu yang lama.

\section{KESIMPULAN}

Desa Kranggan merupakan desa wisata dan juga merupajan desa "home industry" yang di yang berlokasi di kecamatan Setu, Kabupaten Tangerang. Desa tersebut mempunyai permasalahan sampah yang serius dan dibutuhkan peran akademisi (universitas) untuk mengedukasi masyarakat setempat tentang pengelolaan sampah. Universitas Swiss German sebagai salah satu universitas swasta di Indonesia memainkan peran penting dalam mengedukasi masyarakat desa Kranggan tentang manajemen sampah serta memfasilitasi tempat pembakaran sampah yang effektif yang dapat di daur ulang kembali sampah tersebut sehingga dapat meningkatkan ekonomi masyarakat desa Kranggan. Universitas Swiss German mendesign alat insenerator yang sederhana sehingga mudah untuk dimanfaatkan dan dikelola oleh masyarakat desa Kranggan sehingga berdampak terhadap lingkungan desa Kranggan. Namun dari hasil evaluasi dan observasi di temukan bahwa 2 alat yang ditempatkan di are berbeda tidak dimanfaatkan dengan baik oleh masyarakat setempat sehingga berdampak terhadap lingkungan di 2 area berbeda tersebut. Berbeda hal nya dengan area 1 yang memaksimalkan pemanfaatan alat insinerator sederhana tersebut, namun dikarenakan ketidaktahanan material pada alat tersebut, menyebabkan kerusakan dan dbutuhkan mendisign ulang dan membuat kembali alat tersebut sehingga mampu dimanfaatkan dalam waktu yang lama.

Dengan hasil evaluasi ini menuntut dibuatnya metode dan cara baru agar meningkatkan kesadaran masyarakat desa Keranggan penting nya pengunaan alat tersebut sehingga nanti nya berdampak terhadap lingkungan desa Keranggan. Adapun metode dan cara yang dapat digunakan adalah dengan merekruit/melibatkan beberapa warga setempat untuk mengumpulkan sampah-sampah di rumah warga dan membawanya ke tempat pembakaran sampah yang dimana alat insinerator tersebut di tempatkan. Mendesign ulang alat insinerator yang telah rusak agar dapat dipakai dalam waktu yang lama serta dibuatkan kembali dengan design baru tersebut. Menambah pembuatan alat insinerator sehingga dapat mencakupi seluruh wilayah desa Keranggan serta memberikan eduksi yang berterusan kepada masyarakat penting nya menjaga lingkungan Desa Keranggan.

\section{UCAPAN TERIMAKASIH (Bila ada)}

Ucapan terimakasih disampaikan kepada lembaga/institusi yang telah memberikan kontribusi dalam pelaksanaan kegiatan.

Ucapan terima kasih disampaikan kepada lembaga/i nstitusi an nomor kegiatan (bila ada) serta tahun.

\section{REFERENSI}

Chandra, B. (2006). Pengantar Kesehatan Lingkungan. Jakarta: EGC.

Fadhilah, A., Sugianto, H., Hadi, K., Firmandhani, S. W., Murtini, T. W., \& Pandelaki, E. E. (2011,August). Kajian Pengelolaan Sampah Kampus Jurusan Arsitektur Fakultas Teknik Universitas Diponegoro.

Morgan, S. (2009). Daur Ulang Sampah. Solo: Tiga Serangkai.

Notoatmodjo, S. (2010). Ilmu Kesehatan Masyarakat dan Prinsip-Prinsip Dasar. Cipta, Jakarta.

P3M, P. P. (2014, Juni 1). Pengelolaan Sampah Mandiri Ramah Lingkungan Skala Rumah Tangga Studi Kasus Desa Cupang. SCIENTIAE EDUCATIA, p. Volume 3.

Qodriyatun, S. N. (2014). Meningkatkan Kesejahteraan Masyarakat Melalui Pengelolaan Sampah Berdasarkan UU N0. 18 Tahun 2008. Aspirasi. Standard, N. I. (2008). Pengelolaan Sampah di Pemukiman.

Lingkungan Hidup dan Bencana

704 
Tobing, I. S. (2005). Dampak Sampah Terhadap Kesehatan Lingkungan dan Manusia. Aspek Lingkungan dan Legalitas Pembuangan Sampah serta Sosialisasi Pemanfaatan Sampah Organik Sebagai Bahan Baku Pembuatan Kompos . Jakarta.

Trisaksono Bagus, P. (2002). Pengelolaan dan Pemanfaatan Sampah Menggunakan Teknologi Incenerator. Jurnal Teknologi Lingkungan, 17-23.
Yasa, I., M, T., \& Sudiarsa, I. M. (2012, Maret 2). Pengelolaan Sampah Dengan Konsep 3R Studi Kasus: Kecamatan Denpasar Selatan (Kodya Denpasar). Jurnal Matrix, pp. 51-56. 